\title{
Three-Sector Structure of the National Economy of Russia
}

\author{
I. Sh. Khasanov ${ }^{1}$ \\ ${ }^{1}$ Kazan Federal University, Russian Federation \\ Correspondence: I. Sh. Khasanov, Kremliovskaya str. 18, Kazan, 420008, Russian Federation. E-mail: \\ ilgizarkhasan@mail.ru
}

Received: June 30, 2014 Accepted: July 29, 2014 Online Published: September 28, 2014

doi:10.5539/ass.v10n20p217 URL: http://dx.doi.org/10.5539/ass.v10n20p217

\begin{abstract}
The main objective of the article is to determine the changes in the income and expenditure of the national economy of Russia from 1961 to 2009. To solve this problem, the author applied research methodology of the economic system-a three-sector static equilibrium income and expenses using a statistical system of national accounts. As a result, on the basis of the methodology found an association between income and expenditure of the three sectors (economic activities) of the national economy: the production of products and services for production purposes, the production of consumer goods and production of financial and credit services.
\end{abstract}

Keywords: static equilibrium in the economy, the structure of the national economy, sectors of economy, gross domestic product, income and expenses

\section{Introduction}

When dividing the economy into three sectors, all business entities engaged in production of goods and services on the territory of Russia are taken into account.

The state sector refers to the set of entities that are controlled by the state through federal government bodies and regional government bodies of the Federation, the municipal sector-to the set of entities that are controlled by local governments. The private sector includes entities that are not a part of the public and municipal sectors, as well as natural persons conducting business activity without incorporation. The state and municipal sectors together form the so-called public sector.

In foreign practice, as a rule, more specific criteria are used to indicate boundaries of the state sector, in some cases, it refers to enterprises, state ownership of which makes up to more than $50 \%$, but often less strict standards are applied.

In France, there is an annually updated list of official state-owned enterprises, which include legal entities with state participation of more than $30 \%$ (including subsidiaries).

In Turkey, where the fairly efficient state sector is formed relatively recently, all companies are divided into two groups-state economic enterprises (SEE) and state economic organizations (SEO). SEEs are defined as legal entities with government-owned capital operating in accordance with the principles of the market economy, and SEOs-as legal entities with government-owned capital, engaged in production and distribution of a particular product, volume, assortment and prices of which are set by the state (GEOs usually refer to monopolies). And both of them have a "three-tier" structure, i.e. consist of business units, the entire capital of which is owned by the state (establishments), subsidiaries, where the state owns more than $50 \%$ of the capital, and entities with the state interests $15-50 \%$ (participations).

In most Western countries the notion of a two-sector economy is used: from the point of view of the state's participation in economic structures activities, the national economy is generally divided into the state or public and non-governmental, or private sectors.

China follows a different classification-all business according to property specifications are divided into three groups-states, private, mixed.

Thus, the three-sector model of the Russian economy in comparison with international practice has its own characteristics.

The composition of the public sector 
Specifying the above given general definition of the state sector, in the Russian economy its business entities may be as follows:

- state unitary enterprises;

- state agencies;

- joint-stock companies, in authorized capitals of which more than $50 \%$ of voting shares are in federal ownership and (or) in property of subjects of the Federation;

- subsidiaries whose head (parent) companies are a part of the state sector;

- entities included into a holding company, the head (parent) company of which refers to the state sector.

Under the direct control of the state, the state sector makes it possible to use direct administrative regulation measures in contrast to general measures of macroeconomic regulation, mainly relating to indirect methods. This enables to influence volume, structure (range) and prices of products in the most powerful and precise manner and to promptly put strategic decisions into practice. The state sector enterprises have a great potential in formatting a long-term production and investment strategy.

In order to streamline the system of the state sector management, it is necessary to draw a clear distinction between its companies according to management entity criterion (the federal level and the level of subjects of the Federation). Each type of enterprises should be managed by the representative of the relevant branches of government; intervention of other branches is unacceptable.

In special cases where enterprise activities affect interests of both branches of government, equity participation can be practiced in management. In this regard, it is necessary to distinguish between different segments of the state sector (federal state sector with the dominance of the federal centre in enterprises property, regional state sector with the dominance of subjects of the Federation in enterprises property, mixed state sector, where the combined share of federal and regional government bodies dominates in enterprises property, but there is no complete dominance of one of the branches of government).

To pursue an active state policy on mixed enterprises of the state sector, one must define the body in charge of their activities, as well as the mechanism of decision-making and coordination between the different branches of government. Decisions implementing should be in accordance with the status of economic structure with mixed ownership, i.e. by a vote of the shareholders.

To eliminate possible organizational and legal conflicts between different branches of government on the state sector management of mixed enterprises, an appropriate mechanism should be elaborated and institutionalized in legal acts.

In developing policies aimed to reform the state sector, it is useful to refer to foreign experience in terms of principles of their formation.

In EU countries, the presence of state-owned enterprises is justified in the following cases:

When within the private sector macroeconomic optimum conditions cannot be achieved (especially in cases of natural monopolies), and also when it comes to the need of maintaining low-profit or capital-intensive, but necessary for the of society productions and enterprises, where the private sector does not want to engage in (infrastructure, ecological companies, some types of high-tech industries, etc.);

When the state seeks to control relevant to the economy or the defence of the country industries, especially if there is a threat to the transition of such companies to the full control of TNCs;

when the government wants to have tools for regulating economic, in particular, investment activities or for modernization of the economy through corresponding programmes of research and development;

When it is necessary to ensure inter-sectorial reallocation of resources if private agents are unable to do so;

When it is necessary to pursue a focused regional policy related to development of new areas and development of backward areas, creation of new productions, infrastructure and jobs in those areas.

The most important principle of positive functioning of the economic system is a balance: between production and consumption, trade and monetary circulation, aggregate supply and demand; revenues and expenditures; material and personal factors of production, consumption and accumulation; sectors producing capital and consumer goods, manufacturing products and providing services, transformational and transactional sectors, exports and imports, trade and balance of payments and other areas of economic life. Under equilibrium author understood balanced interaction (transaction) between the separate spheres of the national economy, contributing 
to its growth.

Methodological principle of equilibrium in the study of the economic system has led many scientists to develop various static models of economic development. During the XX century, many economists analyzed the problem of static economic system. Most scientists understand economic statics as equilibrium theory of national economy or static economy, which is economy in a state of equilibrium (Schumpeter, 1908; Schumpeter, 1912; Jevons, 1911; Walras, 1988; Marshall, 1910; Clark, 1899; Clark, 1922; Pareto, 1909; Fisher, 1892; Seligman, 1905; Tanssig, 1923; Cassel, 1918; Oppenheimer, 1922; Oppenheimer, 1911; Streller, 1926; Badge, 1925). Analysis of the economic problems in normal conditions, which is in equilibrium, is static in nature.

Consideration of the equilibrium state of the economic system has led scientists to study the interaction of individual elements of which it is composed. Study of equilibrium of the economic system means designing circuits for establishing equilibrium of its elements. The main objective is the optimal economic statics analysis of the structure and interaction of the elements of the national economy, the achievement of the overall proportion and balance of the economy.

\section{The Equilibrium Structure of the National Economy of Russia on Income and Expenditure}

The national economy is characterized by many macroeconomic indicators, but most important of which are the gross output of products and services (GO) gross domestic product (GDP), the accumulation of real and financial assets, net lending $(+)$ /net borrowing $(-)$. The above macroeconomic indicators are interrelated with each other. If the absolute value of GDP taken for 10,000 currency units or $10000 \%$, in a formalized way, gross output of products and services can be represented by the following equation:

$$
c\left(c^{\prime}+c^{\prime}\right)+v+m=w
$$

where: w-gross output at market prices; c'-material costs or intermediate consumption; c"-depreciation (depreciation cost of capital); v-workers' wages (including taxes and insurance deductions, hidden wages); m-gross profit and net mixed income (including taxes on products, net taxes on production and non-tax payments).

We have calculated the structure of gross output and gross domestic product of Russia for 50 years (for the period from 1961 to 2009). The resulting calculations for some years can be summarized as follows:

1961 year:

$$
11306 c\left(10200 c^{\prime}+1106 c^{\prime \prime}\right)+4484 v+4410 m=20200 w
$$

1970 year:

$$
11884 c\left(10673 c^{\prime}+1211 c^{\prime \prime}\right)+4554 v+4235 m=20673 w
$$

1982 year:

$$
12177 c\left(10485 c^{\prime}+1692 c^{\prime \prime}\right)+4363 v+3945 m=20485 w
$$

1991 year:

$$
9857 c\left(9042 c^{\prime}+815 c^{\prime \prime}\right)+4367 v+4818 m=19042 w
$$

2008 year:

$$
9379 c\left(8761 c^{\prime}+663 c^{\prime \prime}\right)+4562 v+4775 m=18716 w
$$

2009 year:

$$
9828 c\left(8934 c^{\prime}+894 c^{\prime \prime}\right)+5174 v+3932 m=18934 w
$$

Gross domestic product at market prices is defined as the difference between gross output at market prices (w) and intermediate consumption (c'), for example, in 2009:

$$
18934 \mathrm{w}-8934 \mathrm{c}^{\prime}=10000 v v p\left(894 c^{\prime \prime}+5174 v+3932 m\right)
$$

where: vvp-gross domestic product at market prices (actual).

On the basis of the national accounts statistics were calculated gross domestic product of the Russian Federation by three methods (production, generation of income and end-use) for years 1961-2011. We determined the structure of gross domestic product (GDP) by three methods as following equations:

1) The production method: 


$$
c^{\prime \prime}+v+m\left(m^{\prime}+n^{\prime}\right)=v v p
$$

2) Method of income:

$$
c^{\prime \prime}+v+m\left(n^{\prime}+n^{\prime \prime}+p\right)=v v p
$$

3) By end use:

$$
\Delta c^{\prime}+\left(c^{\prime \prime}+\Delta+\Delta\right)+(v+\Delta v)+m / x+o+r=v v p
$$

where: $n^{\prime}$-net taxes on products or indirect taxes (VAT, excise duties and import-export duties); n"-net taxes on production or direct taxes; $p$-net income and net mixed income; $\Delta \mathrm{c}^{\prime}$-increase in inventories; $\Delta \mathrm{c}$ "-capital formation; $\Delta \mathrm{v}$-consumed part of gross income and net mixed income of employed workers; $\mathrm{m} / \mathrm{x}$-part of gross income and net mixed income institutional units earmarked for the purchase of financial assets; x-number not zero, which divide the gross profit and net mixed income for consumption and accumulation; o-rest of the money (different income and transfers) or "idle money"; r-a statistical discrepancy.

Using these schemes in market prices, was calculated the GDP by the formation of primary income (distribution method). In this case, GDP is defined as the sum: $c^{\prime \prime}+v+m\left(n^{\prime}+n^{\prime \prime}+p\right)=v v p$.

1961 year:

$$
1106 c^{\prime \prime}+4484 v+4410 m\left(1989 n^{\prime}+41 n^{\prime \prime}+2380 p\right)=10000 v v p
$$

1970 year:

$$
1211 c^{\prime \prime}+4554 v+4235 m\left(1306 n^{\prime}+107 n^{\prime \prime}+28226 p\right)=10000 v v p
$$

1982 year:

$$
1692 c^{\prime \prime}+4363 v+3945 m\left(1865 n^{\prime}+113 n^{\prime \prime}+1967 p\right)=10000 v v p
$$

1991 year:

$$
815 c^{\prime \prime}+4367 v+4818 m\left(364 n^{\prime}+80 n^{\prime \prime}+4374 p\right)=10000 v v p
$$

2008 year:

$$
663 \mathrm{c}^{\prime \prime}+4562 v+4775 \mathrm{~m}\left(1508 \mathrm{n}^{\prime}+514 \mathrm{n}^{\prime \prime}+2753 \mathrm{p}\right)=10000 \mathrm{vvp}
$$

2009 year:

$$
894 c^{\prime \prime}+5174 v+3932 m\left(1254 n^{\prime}+390 n^{\prime \prime}+2280 p\right)=10000 v v p
$$

According to statistical data through the use of GDP in 1961-2009 years was used in the following areas (Table 1):

$$
c^{\prime \prime}+v+\Delta v+\Delta c^{\prime}+\Delta c^{\prime \prime}+m / x+o+r=v v p
$$

Based on the structure of Russia's GDP, we can write the equation of exchange or balance income and expenditure, for example on the following data:

1961 year:

$$
\begin{aligned}
& \left.c^{\prime \prime}+\Delta c\right)+8028(v+\Delta v)+58 m / x+o-100 r \\
& 1106 c^{\prime \prime}+4484 v+4410 m\left(1989 n^{\prime}+41 n^{\prime \prime}+2380 p\right)=417 \Delta c^{\prime}+1597
\end{aligned}
$$

1970 year:

$$
\begin{aligned}
& \left.c^{\prime \prime}+\Delta c\right)+7524(v+\Delta v)+71 m / x+o-13 r \\
& 1211 c^{\prime \prime}+4554 v+4235 m\left(1306 n^{\prime}+107 n^{\prime \prime}+2822 p\right)=390 \Delta c^{\prime}+2028
\end{aligned}
$$

1982 year:

$$
\begin{aligned}
& \left.c^{\prime \prime}+\Delta c\right)+6909(v+\Delta v)+129 m / x+50 o-82 r \\
& 1692 c^{\prime \prime}+4363 v+3945 m\left(1865 n^{\prime}+113 n^{\prime \prime}+1967 p\right)=459 \Delta c^{\prime}+2471
\end{aligned}
$$

1991 year: 


$$
\begin{aligned}
& \left.c^{\prime \prime}+\Delta c\right)+6119(v+\Delta v)+28 m / x+o-229 r \\
& 815 c^{\prime \prime}+4367 v+4818 m\left(364 n^{\prime}+80 n^{\prime \prime}+4374 p\right)=1301 \Delta c^{\prime}+2323
\end{aligned}
$$

2008 year:

$$
\begin{aligned}
& \left.c^{\prime \prime}+\Delta c\right)+6537(v+\Delta v)+1 m / x+602 o-309 r \\
& 663 c^{\prime \prime}+4562 v+4775 m\left(1508 n^{\prime}+514 n^{\prime \prime}+2753 p\right)=361 \Delta c^{\prime}+2192
\end{aligned}
$$

2009 year:

\begin{tabular}{|c|c|c|c|c|c|c|c|c|c|}
\hline Year & $\begin{array}{l}\text { Gros } \\
\text { s } \\
\text { outp } \\
\text { ut } \\
\text { w }\end{array}$ & $\begin{array}{l}\text { Intermedi } \\
\text { ate } \\
\text { consumpti } \\
\text { on } \\
\text { c' }^{\prime}\end{array}$ & $\begin{array}{l}\text { Gross } \\
\text { domestic } \\
\text { product } \\
\text { vvp }\end{array}$ & $\begin{array}{l}\text { Gross } \\
\text { fixed } \\
\text { capital } \\
\text { forma-tion } \\
\left(\mathbf{c}^{\prime \prime}+\right. \\
\left.+\Delta \mathbf{c}^{\prime \prime}\right)\end{array}$ & $\begin{array}{l}\text { Change } \\
\text { in } \\
\text { working } \\
\text { material } \\
\text { capital } \\
\Delta \mathbf{c}^{\prime}\end{array}$ & $\begin{array}{l}\text { Final } \\
\text { consumptio } \\
\mathrm{n} \\
\text { expen-diture } \\
(\mathbf{v}+\Delta v)\end{array}$ & $\begin{array}{l}\text { Rest of the } \\
\text { money (the } \\
\text { difference } \\
\text { of income } \\
\text { and } \\
\text { transfers) } \\
\text { o }\end{array}$ & $\begin{array}{l}\text { Net } \\
\text { lending } \\
(+) / \text { net } \\
\text { borrowi } \\
\text { ng }(-) \\
\mathbf{m} / \mathbf{x}\end{array}$ & $\begin{array}{l}\text { statistical } \\
\text { dis-crepa } \\
\text { ncy } \\
\mathbf{r}\end{array}$ \\
\hline 1 & $\begin{array}{l}2(3+ \\
4)\end{array}$ & 3 & $\begin{array}{l}4(5+6+7+ \\
+8+9++10)\end{array}$ & 5 & 6 & 7 & 8 & 9 & 10 \\
\hline 1961 & $\begin{array}{l}2020 \\
0\end{array}$ & 10200 & 10000 & 1597 & 417 & 8028 & $*$ & 58 & -100 \\
\hline 1970 & $\begin{array}{l}2067 \\
3\end{array}$ & 10673 & 10000 & 2028 & 390 & 7524 & $*$ & 71 & -13 \\
\hline 1982 & $\begin{array}{l}2048 \\
5\end{array}$ & 10485 & 10000 & 2471 & 459 & 6909 & -50 & 129 & 82 \\
\hline 1991 & $\begin{array}{l}1904 \\
2\end{array}$ & 9042 & 10000 & 2323 & 1301 & 6119 & $*$ & 28 & 229 \\
\hline 1998 & $\begin{array}{l}1833 \\
1\end{array}$ & 8331 & 10000 & 1615 & -119 & 7620 & 468 & 199 & 217 \\
\hline 1999 & $\begin{array}{l}1824 \\
2\end{array}$ & 8242 & 10000 & 1439 & 44 & 6812 & 387 & 1318 & 0 \\
\hline 2008 & $\begin{array}{l}1871 \\
6\end{array}$ & 8716 & 10000 & 2192 & 361 & 6537 & 309 & 602 & -1 \\
\hline 2009 & $\begin{array}{l}1893 \\
4\end{array}$ & 8934 & 10000 & 2144 & -271 & 7466 & 431 & 304 & -74 \\
\hline
\end{tabular}

$$
\begin{aligned}
& \left.c^{\prime \prime}+\Delta c\right)+7466(v+\Delta v)+74 m / x+304 o-431 r \\
& 894 c^{\prime \prime}+5174 v+3932 m\left(1254 n^{\prime}+309 n^{\prime \prime}+2280 p\right)=-271 \Delta c^{\prime}+2144
\end{aligned}
$$

Table 1. Structure of gross domestic product of Russia from 1991 to 2011

Symbols in the table: ${ }^{*}$-statistics for that year are not available.

\section{Sector Research Methodology of the Economic System}

The modern world and the national economy dividing into markets, areas, scopes, industry activities, sector institutional units and other segments. An important methodological principle study of the global economy is a sector specific approach, which is a form of expression system methodology. Not by chance the world economic theory has practical realization in the development of an international system of national accounts, in which the initial and basic categories are sector institutional unit and type of economic activity. 
Table 2. The revenues from the implementation of the gross output of products and services in the context three sectors of the Russian economy (for the period from 1998 to 2009)

\begin{tabular}{|c|c|c|c|c|c|c|c|c|}
\hline Year & $\begin{array}{l}\text { Sec-t } \\
\text { ors: } \\
\mathbf{W}_{1} \\
\mathbf{W}_{2} \\
\mathbf{W}_{3} \\
\mathbf{W}\end{array}$ & $\begin{array}{l}\text { Proceeds } \\
\text { from sales } \\
\text { of the } \\
\text { gross } \\
\text { output } \mathbf{W}\end{array}$ & $\begin{array}{l}\text { Proceeds from } \\
\text { the sale of } \\
\text { residents of gross } \\
\text { output in the } \\
\text { domestic market } \\
\mathbf{W}^{\prime}\end{array}$ & $\begin{array}{l}\text { Export } \\
\text { reve-n } \\
\text { ues of } \\
\text { resi-de } \\
\text { nts } \mathbf{E}\end{array}$ & $\begin{array}{l}\text { Expen-di } \\
\text { ture on } \\
\text { imports } \\
\text { of } \\
\text { resi-dent } \\
\text { s I }\end{array}$ & $\begin{array}{l}\text { Balance of } \\
\text { income/exp } \\
\text { enditure on } \\
\text { exports and } \\
\text { imports (e-i) }\end{array}$ & $\begin{array}{l}\text { statis-tic } \\
\text { al } \\
\text { dis-crepa } \\
\text { ncy } \\
\mathbf{R}\end{array}$ & $\begin{array}{l}\text { Gross } \\
\text { domestic } \\
\text { product } \\
\text { vvp }\end{array}$ \\
\hline \multirow[t]{2}{*}{1} & 2 & $3(4+7+8)$ & 4 & 5 & 6 & $7(5-6)$ & 8 & 9 \\
\hline & $\mathrm{W}_{1}$ & 10209 & 8879 & 2846 & 1637 & 1209 & 121 & 1878 \\
\hline \multirow{3}{*}{1998} & $\mathrm{~W}_{2}$ & 7916 & 8358 & 272 & 808 & -536 & 94 & 7916 \\
\hline & $\mathrm{W}_{3}$ & 206 & 210 & 4 & 10 & -6 & 2 & 206 \\
\hline & $\mathrm{W}$ & 18331 & 17447 & 3122 & 2455 & 667 & 217 & 10000 \\
\hline \multirow[t]{4}{*}{2008} & $\mathrm{~W}_{1}$ & 11457 & 10243 & 2944 & 1729 & 1215 & -1 & 2741 \\
\hline & $\mathrm{W}_{2}$ & 6647 & 6942 & 146 & 442 & -295 & 0 & 6647 \\
\hline & $\mathrm{W}_{3}$ & 612 & 621 & 12 & 21 & -9 & 0 & 612 \\
\hline & W & 18716 & 17806 & 3102 & 2191 & 911 & -1 & 10000 \\
\hline \multirow[t]{4}{*}{2009} & $\mathrm{~W}_{1}$ & 11015 & 9939 & 2584 & 1465 & 1119 & -43 & 2081 \\
\hline & $\mathrm{W}_{2}$ & 7609 & 8011 & 177 & 549 & -372 & -30 & 7609 \\
\hline & $\mathrm{W}_{3}$ & 310 & 323 & 12 & 24 & -12 & -1 & 310 \\
\hline & $\mathrm{W}$ & 18934 & 18273 & 2773 & 2038 & 735 & -74 & 10000 \\
\hline
\end{tabular}

Table 3. Areas of spending cash proceeds from the sale of the gross output by three sectors of the Russian economy for the period from 1998 to 2009

\begin{tabular}{|c|c|c|c|c|c|c|c|c|}
\hline Year & $\begin{array}{l}\text { Gross } \\
\text { output W }\end{array}$ & $\begin{array}{l}\text { Consumption } \\
\text { by organizati } \\
\text { industries (sec } \\
\text { Including } \\
\text { Intermediate } \\
\text { consumptio } \\
\mathrm{n} \quad \text { for } \\
\text { reimbur-sem } \\
\text { ent of } \\
\text { material } \\
\text { costs) } \mathbf{c}^{\prime}\end{array}$ & $\begin{array}{l}\text { Gross } \\
\text { accumu-la } \\
\text { tion of the } \\
\text { fixed } \\
\text { capital } \\
c^{\prime \prime}+\Delta c\end{array}$ & $\begin{array}{l}\text { Total } \\
\mathbf{W}_{1} \\
\left(\mathbf{c}^{\prime}+\mathbf{c}^{\prime \prime}+\right. \\
+\Delta \mathbf{c})\end{array}$ & $\begin{array}{l}\text { Consumption of } \\
\text { products and services } \\
\text { by orga-nizations of } \\
\text { the group II industries } \\
\text { or the final } \\
\text { con-sumption } \\
\text { expen-ditures of the } \\
\text { population } \\
\text { (sector B) } \\
\mathbf{W}_{\mathbf{2}}(\mathbf{v}+\Delta \mathbf{v})\end{array}$ & $\begin{array}{l}\text { Consumption of } \\
\text { products and } \\
\text { services by } \\
\text { organiza-tions } \\
\text { of the group III } \\
\text { in-dustries } \\
\text { (sec-tor C) or } \\
\text { net lending (+) } \\
\text { or net } \\
\text { borro-wing(-) } \\
\mathbf{W}_{\mathbf{3}} \mathbf{m} / \mathbf{x}\end{array}$ & $\begin{array}{l}\text { Cash } \\
\text { balan- } \\
\text { ces of } \\
\text { money } \\
\text { "Idle } \\
\text { money } \\
\text { " }\end{array}$ & $\begin{array}{l}\text { statis- } \\
\text { tical } \\
\text { dis-cr } \\
\text { e-pan } \\
\text { cy } \mathbf{r}\end{array}$ \\
\hline 1 & $\begin{array}{l}2(5+6+ \\
+7+8++9)\end{array}$ & 3 & 4 & $\begin{array}{l}5 \\
(3+4)\end{array}$ & 6 & 7 & 8 & 9 \\
\hline 1998 & 18331 & 8331 & 1496 & 9827 & 7620 & 199 & 468 & 217 \\
\hline 1999 & 18242 & 8242 & 1483 & 9725 & 6812 & 1318 & 387 & 0 \\
\hline 2000 & 18322 & 8322 & 1870 & 10192 & 6128 & 2157 & -155 & 0 \\
\hline 2001 & 19031 & 9031 & 2195 & 11226 & 6582 & 797 & 471 & -45 \\
\hline 2002 & 18687 & 8687 & 2003 & 10690 & 6873 & 515 & 562 & 47 \\
\hline 2003 & 18792 & 8792 & 2081 & 10873 & 6813 & 799 & 336 & -29 \\
\hline 2004 & 18601 & 8601 & 2088 & 10689 & 6688 & 969 & 255 & 0 \\
\hline 2005 & 18582 & 8582 & 2006 & 10588 & 6621 & 937 & 432 & 4 \\
\hline 2006 & 18685 & 8685 & 2137 & 10822 & 6553 & 962 & 310 & 38 \\
\hline 2007 & 18884 & 8884 & 2426 & 11310 & 6580 & 517 & 342 & 135 \\
\hline 2008 & 18716 & 8716 & 2553 & 11269 & 6537 & 602 & 309 & -1 \\
\hline 2009 & 18934 & 8934 & 1873 & 10807 & 7466 & 304 & 431 & -74 \\
\hline
\end{tabular}

World economic science is on the long road from research transactions between two units of social reproduction (by K. Marx), between the three departments of production and consumption (by M. I. Tugan-Baranovsky) 
between the sectors producing capital and consumer goods, savings and investment, aggregate demand and supply (by D. Keyns) between transformational and transactional sectors of the national economy (by D. North and J. Wallis) and the transition to the study of mega transactions between the real and financial sectors of the world economy and between different segments of the global economic system (production and consumption, saving and accumulation, etc.). With the help of statistical data of the international system of national accounts recorded inter sector transactions (from Latin transaction means interaction) undertaken in the global and national economic system. The author of the article was made division of the national economy in the context of the three groups of industries (sectors): industries producing capital goods and production services to organizations $\left(\mathrm{W}_{1}\right)$; industries producing consumer goods and services to the public $\left(\mathrm{W}_{2}\right)$ and industries, rending financial services (banking, insurance, investment and other) to organizations and people $\left(\mathrm{W}_{3}\right)$ (Table 2).

Gross domestic product may also be represented by final use. Feature of this method is that the distribution and redistribution of income is used by institutional units to the ultimate goals of consumption and accumulation. Define their constituent elements and the actual quantity. Then was calculated element structure of gross output and gross domestic product of Russia by end-use in the context of the three products sectors for the period 1998 to 2009 (Table 3).

\section{Results}

Let' refer to the data in Tables 2 and 3. The calculated data of the tables allow to formalize the exchange of goods in the three sectors of the natural-real and monetary terms, as well as to balance income and expenditure in the national economy. As an example, we use the appropriate values for the year 1998.

Total revenues from the sale of the gross output of the three sectors were:

I.

$$
8879 \mathrm{w}_{1}{ }^{1}\left(\mathrm{c}_{1}{ }^{1}+\mathrm{v}_{1}{ }^{1}+\mathrm{m}_{1}{ }^{1}\right)+1209\left[w_{1}{ }^{2}\left(c_{1}{ }^{2}+v_{1}{ }^{2}+m_{1}{ }^{2}\right)-w_{1}{ }^{3}\left(c_{1}^{3}+v_{1}^{3}+m_{1}^{3}\right)\right]+121 r_{1}=10209 w_{1}
$$

II.

$$
8358 \mathrm{w}_{2}{ }^{1}\left(\mathrm{c}_{2}{ }^{1}+\mathrm{v}_{2}{ }^{1}+\mathrm{m}_{2}{ }^{1}\right)-536\left[w_{2}{ }^{2}\left(c_{2}{ }^{2}+v_{2}{ }^{2}+m_{2}{ }^{2}\right)-w_{2}{ }^{3}\left(c_{2}{ }^{3}+v_{2}{ }^{3}+m_{2}{ }^{3}\right)\right]+94 r_{2}=7916 w_{2}
$$

III.

$$
210 \mathrm{w}_{3}{ }^{1}\left(\mathrm{c}_{3}{ }^{1}+\mathrm{v}_{3}{ }^{1}+\mathrm{m}_{3}{ }^{1}\right)-6\left[w_{3}{ }^{2}\left(c_{3}{ }^{2}+v_{3}{ }^{2}+m_{3}{ }^{2}\right)-10 w_{3}{ }^{3}\left(c_{3}{ }^{3}+v_{3}{ }^{3}+m_{3}{ }^{3}\right)\right]+2 r_{3}=206 w_{3}
$$

(I+II+III).

$$
17447 \mathrm{w}^{1}\left(\mathrm{c}^{1}+\mathrm{v}^{1}+\mathrm{m}^{1}\right)+667\left[w^{2}\left(c^{2}+v^{2}+m^{2}\right)-w^{3}\left(c^{3}+v^{3}+m^{3}\right)\right]+217 r_{3}=18331 w
$$

Total expenditure on final consumption of products and services sectors accounted for three (I+II+III):

$$
18331 w=9827 w_{1}\left|8331 c^{\prime}+1496\left(c^{\prime \prime}+\Delta c^{\prime}+\Delta c^{\prime \prime}\right)\right|+7620 w_{2}(v+\Delta v)+199 w_{3}(m / x)+468 o+217 r
$$

Hence we can write the system of equations of revenues and expenses and natural-real value for the year 1998:

I.

$$
\begin{aligned}
& 8879 \mathrm{w} 11(c 11+v 11+m 11)+1209[w 12(c 12+v 12+m 12)-w 13(c 13+v 13+m 13)]+121 \mathrm{r} 1= \\
& 9827 \mathrm{w} 1\left[8331 \mathrm{c}^{\prime}+1496\left(c^{\prime \prime}+\Delta+\Delta c^{\prime}+4\right)\right]+121 \mathrm{r} 1+261 o 1=10209 \mathrm{w} 1
\end{aligned}
$$

II.

$$
8358 w_{2}^{1}\left(c_{2}^{1}+v_{2}^{1}+m_{2}^{1}\right)-536\left[w_{2}^{2}\left(c_{2}^{2}+v_{2}^{2}+m_{2}^{2}\right)-w_{2}^{3}\left(c_{2}^{3}+v_{2}^{3}+m_{2}^{3}\right) \mid+94 r_{2}=7620 w_{2}(v+\Delta v)+94 r_{2}+202 o_{2}=7916 w_{2}\right.
$$

III.

$$
\left.210 w_{31}\left(c_{3^{1}}+v_{3^{1}}+m_{3^{1}}\right)-6 \mid w_{3^{2}}\left(c_{3^{2}}+v_{3^{2}}+m_{3^{2}}\right)-w_{3^{3}}\left(c_{3^{3}}+v_{3^{3}}+m_{3^{3}}\right)\right]+2 r_{3}=199 w_{3}(m / x)+2 r_{3}+5 o_{3}=206 w_{3}
$$




\section{Conclusion}

Transactional approach to the study of the economic system revealed the real and natural- cash proportion and balance between incomes and expenses in the three major sectors of the national economy: the sector producing capital goods and industrial services providing to organizations (sector B), sector producing consumer goods and providing services to population (sector A) and sector providing financial services to organizations and population (sector C). Figure 1 presents data on the percentage of sectors $\mathrm{A}, \mathrm{B}$ and $\mathrm{C}$ in a total volume of Russia's GDP (in percent).

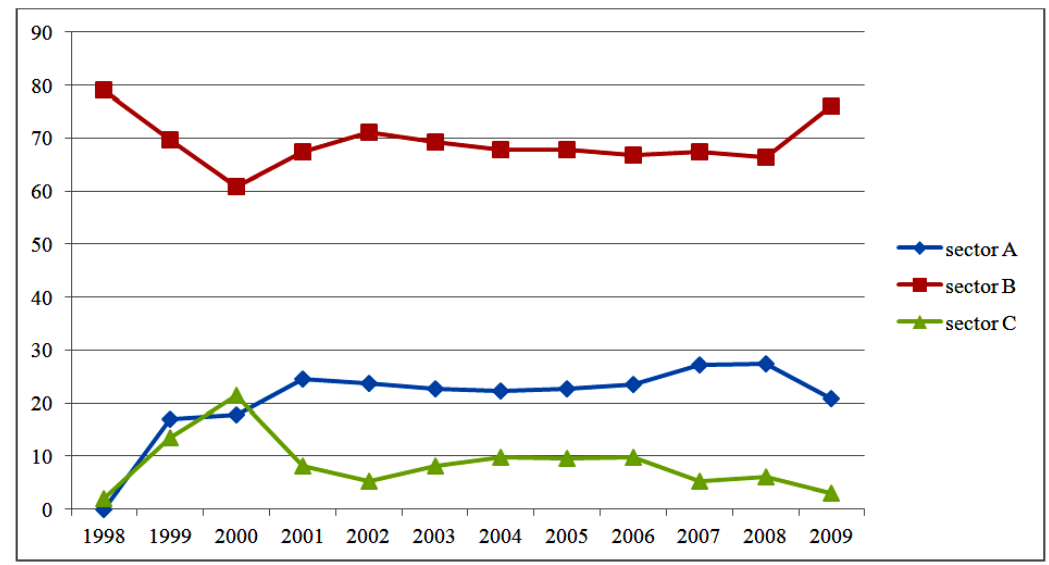

Figure 1. Share of sectors A, B and C in the consumption of Russia's GDP

Indicators (Table 3 and Figure 1) shows, that the financial sector has a small share in the national economy. Consequently, there is a decline in the share of the financial sector in the national economy of Russia.

\section{References}

Badge, S. (1925). Grundzuge der theoretischen Nationalokonomie (p. 8). In G. J. Cassel (Ed.), Theoretische Sozialokonomie (pp. 68-73). Leipzig.

Clark, J. B. (1899). The distribution of wealth (pp. 29-30). New York.

Clark, J. B. (1922). Essentials of economic theory (pp. 127-145). New York.

Fisher, I. (1892). Mathematical investigations in the theory of value and prices. Transactions of the Connecticut Academy of Arts and Sciences, 9(1), 1-124.

Jevons, S. W. (1911). The theory of political economy (pp. 93-94).

Marshall, A. (1910). Principles of economics (pp. 366-367).

Oppenheimer, F. (1924). Theorie der reinen und politischen Okonomie. System der soziologie (p. 619). Jena: G. Fischer.

Pareto, V. (1909). Manuel d'economie politique (p. 147).

Safiullin, L., Gafurov, I., Shaidullin, R., \& Safiullin, N. (2014). Socio-economic development of the region and its historical and cultural heritage. Life Science Journal, 11(6s), 400-404.

Seligman, E. (1905). Principles of economics (p. 224). Bombay.

Streller, R. (1926). Static and dynamic in der theoretischen Nationalokonomie (p. 43). Leipzig.

Taussig, F. W. (1939). Principles of economics (4th ed.). New York: Macmillan.

Walras, L. (1988). Elements d'economie politique pure (p. 366). Lausanne, L. Corbaz; Paris, Economica.

\section{Copyrights}

Copyright for this article is retained by the author(s), with first publication rights granted to the journal.

This is an open-access article distributed under the terms and conditions of the Creative Commons Attribution license (http://creativecommons.org/licenses/by/3.0/). 